\title{
An estimate of the water budget for the endangered night parrot of Australia under recent and future climates
}

\author{
Michael R. Kearney ${ }^{1 *}$, Warren P. Porter ${ }^{2}$ and Stephen A. Murphy ${ }^{3,4}$
}

\begin{abstract}
Background: Endangered species management must now incorporate the potential effects of climate change, but this is often in the context of limited data. The endangered night parrot was recently rediscovered in the Australian arid zone and a major effort is underway to ensure its survival. A key question is to what extent it is dependent on standing water under current and future climates, as this has major implications for understanding and managing its habitat requirements. However, very little is known about its ecology and physiology, and its conservation status precludes invasive ecophysiological studies.
\end{abstract}

Method: Here we show how the methods of biophysical ecology permit strong inferences about this problem with minimal data. We developed a biophysical model of both the parrot and its habitat at the site of its rediscovery. We used allometrically-adjusted observations of the known physiology of a closely related desertadapted Australian parrot, the budgerigar, to infer unknown aspects of the night parrot's physiological responses, together with plumage measurements from museum specimens. We tested the microclimate model against empirical data on microhabitat temperatures and compared the endotherm model predictions against an infra-red thermograph of the bird itself. We then used the model to predict the frequency with which the parrot would need to find standing water under current and future climates depending on the water content of its food.

Results: Our field data show that air temperature in night parrot roosts during high summer typically exceeds the inferred resting core temperature $\left(38^{\circ} \mathrm{C}\right)$ and can exceed $45^{\circ} \mathrm{C}$. Our calculations imply that night parrots can persist on dry seed during winter conditions without exceeding dangerous levels of dehydration, but would need access to water or succulent (55\% water) food during summer. Air temperature at the site is projected to increase $3{ }^{\circ} \mathrm{C}$ by 2070 , which would lead to likely lethal (22\% of body mass) levels of daily dehydration in some years even on succulent food, and would dramatically increase its dependence on standing water.

Conclusion: Our findings have significant implications for the conservation management of the night parrot and provide guidance for future research priorities.

Keywords: Biophysical model, Endangered species, Water budget, Heat stress, Arid zone, Endotherm, Australia

\footnotetext{
* Correspondence: mrke@unimelb.edu.au

'School of BioSciences, The University of Melbourne, Parkville, VIC 3010,

Australia

Full list of author information is available at the end of the article
} 


\section{Background}

The management of endangered species in the wild must now consider the potential influence of future climate change on population persistence $[1,2]$. This should ideally be based on a mechanistic understanding of the connections between species and climate, including basic ecophysiological responses [3]. However, obtaining the required data for developing such an understanding can be extremely difficult with rare and sensitive species. A case in point is the night parrot Pezoporus occidentalis, a species once widespread in the Australian arid zone but for which no confirmed live sightings had been made for around 100 years until 2013, when a single population was discovered in western Queensland. A major effort is now underway to conserve this population and to discover and manage other populations. However, only about 8-10 birds have been observed thus far at the site and research activities are necessarily highly limited.

Birds and mammals have a range of adaptations to arid environments, such as the production of highly concentrated urine and dry faeces, but the physiological challenges of such places for endotherms may be unappreciated [4]. Nocturnal birds such as the night parrot face especially pronounced challenges for two reasons. First, most birds do not use highly thermally buffered retreats such as burrows and caves. Second, nocturnal birds must endure the entire day without water intake from food or drinking and are thus more susceptible to dehydration. The additional heat stress imposed by climate change is thus a serious issue for desert birds such as the night parrot [5]. This is particularly so in Australia where the magnitude of climate warming is predicted to be greatest in the arid zone $[6,7]$ and where major die-off events due to heat waves have been observed previously [5, 8]. McKechnie and Wolf [8] reviewed the issue of climate change impacts on Australian land birds and outlined a conceptual framework for understanding and predicting the effects of climate change on birds in hot environments. They distinguished between the acute and chronic impacts of heat stress on bird survival and reproductive success. In the short term, intense heat waves may kill birds due to excessive dehydration from evaporative cooling responses, and hyperthermia when evaporative cooling responses fail. In the longer term, as climate warming increases the frequency and duration of warm spells, birds may find it harder to balance their water budgets, which may reduce reproductive success or even cause death from chronic dehydration. The ability of birds to deal with stressful climate warming is intimately linked to the availability of buffering microclimates and water in their habitat. The ideal approach for understanding how species might respond to such changes, advocated by McKechnie and Wolf [8], is to develop a mechanistic model of the interactions between the physiological tolerances, behavioural responses and available microclimates. This would allow strong inferences to be made about how their survival, reproduction and habitat requirements will be altered by future climate change.

Our aim in this paper is to develop such a model for the night parrot, with two purposes in mind: 1) to make judgements about the plight of this particular species under recent and future climate change and how this may influence its management, and 2) to illustrate a general approach that can be applied to tackle this kind of problem for other species and habitats. To achieve this we employ the methods of biophysical ecology, which involve the application of physical principles of energy and mass transfer to organisms and their habitats to compute fundamental constraints on a species' behaviour, body temperature and food and water requirements [9-11]. The approach involves solving heat budget equations for organisms subject to the constraints of their particular morphology, physiology and behaviour, as well as habitat constraints on available microclimates. We apply the microclimate and endotherm models of the Niche Mapper biophysical modelling package (now available as an $\mathrm{R}$ package, NicheMapR [12]) in conjunction with historical daily, $5 \mathrm{~km}$ resolution weather grids for Australia [13, 14]. We use this system to compute the heat, energy and water budget of the night parrot at its current known location to ask the following questions:

1) How well can we simulate microclimates available to the night parrot in its habitat?

2) How much water must night parrots lose by evaporation to avoid overheating, and how has this changed in historical times?

3) To what extent can night parrots survive at the site without drinking water, and how is this influenced by dietary water?

4) How will these water requirements change under future climate change scenarios predicted for the site?

\section{Methods}

\section{Study species and site}

The night parrot is one of only two species of parrot worldwide that is fully nocturnal, with partial nocturnality reported in only a handful of other species [15]. Night parrots have long been associated with Triodia spp. [16], an Australian endemic, perennial genus of grasses comprising more than 60 species colloquially known as 'spinifex', most of which form very long lived, dense, spikey hummocks. There are also several credible records of night parrots from chenopod (a salt-tolerant, arid-adapted shrub) dominated systems without Triodia, including the first specimen collected by explorer John McDouall Stuart in 1845 [17]. Early observations, including those made by Aboriginal people [18, 19], museum collectors [16] and graziers [20] suggest that night parrots 
use Triodia hummocks for daytime roosting and nesting. These behaviours have recently been confirmed during an intensive field study on the species in western Queensland (S. Murphy et al., unpubl. data) that is being implemented as part of an environmental offsets agreement [21]. Radioand GPS-tag work on two individual night parrots (a female in April 2015 and a male in April 2016, respectively) revealed that Night Parrots at least sometimes roost during the day in Triodia hummocks and venture out into non-Triodia habitats for most of the night to forage. These habitats include periodically inundated plains with strongly self-mulching clay soils that support a high diversity of mostly ephemeral herbs and annual grasses, and ironstone plains dotted with similarly floristically diverse ephemeral plant communities growing in gilgai formations (Murphy et al. in prep).

Based on limited observations from specimens and a captive live bird in the 1860s, we assume that the night parrot is primarily a granivore $[16,19,22]$. Preliminary molecular analyses based on scats (Murphy et al. in prep.) suggest that Night Parrots feed on a taxonomically diverse range of plants, including grasses (e.g. Triodia longiceps, Brachyachne spp.) and herbs (e.g. Trianthema triquetra). The closely related ground parrot feeds opportunistically on seeds of a wide range of species [23, 24], and preliminary investigations of the night parrot at the Queensland site (S. Murphy in prep.) are consistent with this. However, the night parrot has been observed to prefer green food in captivity [22] and there is circumstantial evidence associating it with a highly succulent desert plant genus, Sclerolaena spp. [25, 26].

Due to concerns about potentially illegal collecting activity, the exact location of the study area in western Queensland is not provided here. However, the population occurs in the Goneaway Tableland subregion of the Interim Biogeographic Regionalisation of Australia (Version 7 [27]); the geographic centroid of this subregion is S 24.1096, E 142.172. Key habitats include (1) Triodia longiceps on very shallow rocky, loamy soils on the slopes and margins of dissected plateaus (2) Sclerolaena spp. dominant over other chenopods on deep clay soils with a surface pavement of ironstone and silcrete, and (3) braided drainages dominated by Acacia cambagei on deep alluvia.

\section{Field observations}

A single night parrot was captured using a mist-net at approximately $1843 \mathrm{~h}$ on 6 May 2016, primarily for fitting a GPS tag to study movements and habitat use, and these results will be reported elsewhere. While in the hand we recorded the bird's mass using a $300 \mathrm{~g}$ Pesola spring balance (Schindellegi, Switzerland) and measured surface skin temperature on the birds' flank using a type-K thermocouple (Digitech QM1601), just below the wing. We also took an infra-red thermograph with a FLIR T420
(FLIR Systems, Inc., Oregon, USA). During handling, we measured air temperature and relative humidity using a hygrochron iButton ${ }^{\circ}$ (Maxim Integrated, San California, USA) suspended approximately $1.5 \mathrm{~m}$ above ground, and wind speed using a WindMate ${ }^{\circ}$ WM-300 handheld anemometer (WeatherHawk, Utah USA) positioned approximately $2 \mathrm{~m}$ above ground. Between December 2015 and January 2016, six iButtons recorded temperature and relative humidity in deep shade $(n=2)$, deep within large Triodia hummocks $(n=2)$, in the open, adjacent to large hummocks $(n=1)$ and in a disused night parrot roost in a relatively smaller hummock that was discovered in April $2015(n=1)$. The roost (Fig. 3e) was in an isolated Triodia hummock (size: $9.8 \mathrm{~m} \mathrm{x} 5.3 \mathrm{~m} \mathrm{x} 0.5 \mathrm{~m} \mathrm{H}$ ). The roost itself was a $25 \mathrm{~cm}$ long, horizontal tunnel, $8 \mathrm{~cm}$ in diameter (at entrance), constructed $8 \mathrm{~cm}$ above ground, with the entrance facing inwards towards the bare centre of the ring-shaped hummock.

\section{Museum measurements}

We measured plumage dimensions of three specimens of the night parrot (36,256, HLW54 and HLW55, collected in the late 1800s) and three specimens of the budgerigar (B25905, B759 and B17320). Specifically, we measured plumage depth at 20 locations from the top of the shoulder to the base of the tail on the dorsal and ventral side (10 per side), as well as the length of three feathers from the dorsal side and three feathers from the ventral side (the latter was only done for two of the three night parrot specimens). We also measured the body dimensions (length from beak to the point at which legs emerged from the feathers, width and depth at the shoulder) from which to obtain a shape estimate.

We measured plumage reflectance at three replicate locations dorsally and ventrally of two of the night parrots (36,256, HLW54). Measurements were made with an Ocean Optics dual-spectrometer system [Ocean Optics, Inc., USA; (Smith et al. 2016)] comprising two spectrometers (USB2000, 300-1000 nm and NIRQuest, 1000$2150 \mathrm{~nm}$ ) with two light sources (PX-2 pulsed Xenon light for the UV-Visrange and HL-2000 tungsten halogen lights for the Vis-NIR range) connected with a quadrifurcated fiber optic ending in a single probe (measurement area of $5 \mathrm{~mm} \times 3 \mathrm{~mm}$ oval). The probe was held in an Ocean Optics RPH-1 probe holder (Ocean Optics, Inc., USA) at a constant angle $\left(45^{\circ}\right)$ and distance (approx. $1 \mathrm{~cm}$ ) from the plumage skin and each measurement was expressed relative to a Spectralon 99\% white reflectance standard (Labsphere Inc., North Sutton, NH, USA). From reflectance spectra, we calculated solar reflectivity, which is a function of reflectance and solar irradiance, from $300-2100 \mathrm{~nm}$ using the ASTM G-173 standard irradiance spectrum for dry air derived from SMARTs v. 2.9.2 [28]. 


\section{Heat budget model}

We applied an R [29] implementation of the endotherm model of the Niche Mapper biophysical modelling package to compute the heat and water budget of the night parrot. This model has been described in detail elsewhere [11,30-32] and is being prepared as a submodule of the NicheMapR biophysical modelling R package [12]. The model takes as input the available microclimatic environments for the organism, under the lowest and highest available shade, and then attempts to solve a heat budget given a specified core temperature and target metabolic rate (e.g. resting metabolic rate). When a solution cannot be found under the assumed initial environment, the program searches through a user-specified sequence of behavioural, morphological and physiological options until a solution is found, which then dictates the location of the animal in its microhabitat and the consequences for its overall energy and water budget for that hour.

All parameters used in our parrot biophysical simulations are summarised in Table 1. As there are no available data on the ecophysiology of the night parrot other than the observations presented in this study, we developed the model based on the known thermal responses of the budgerigar Melopsittacus undulatus which is genetically close to the night parrot [33]. The budgerigar is a small (30 g) arid-adapted, seed-eating parrot with a similar geographic distribution to the historical distribution of the night parrot, and its thermal physiology and water relations are extremely well understood [34-36]. Weathers and Schoenbaechler [36] found, under metabolic chamber conditions during the night, that its body temperature $\left(T_{\mathrm{b}}\right)$ when resting under cold air temperatures $\left(0-16{ }^{\circ} \mathrm{C}\right)$ is 37.7 and its thermal neutral zone was between 29 and $41^{\circ} \mathrm{C}$ (Fig. 2). It will allow $T_{\mathrm{b}}$ to rise to approximately $43^{\circ}$ $\mathrm{C}$ as air temperature rises from $20-45^{\circ} \mathrm{C}$, as is typical for parrots [37]. Weathers and Schoenbaechler [36] also found that water loss rates start to rise at an air temperature of $30{ }^{\circ} \mathrm{C}$ (see also [35]) and increase dramatically from air temperatures of around $39^{\circ} \mathrm{C}$, up to maximum rates of around $35 \mathrm{mg}$ water per gram per hour (Fig. 2), or around $1 \mathrm{~g}$ per hour in absolute terms.

We computed the response of the budgerigar to the metabolic chamber conditions used by Weathers and Schoenbaechler [36] (Table 2), assuming the following morphological, behavioural and physiological responses:

1) a prolate ellipsoid geometry that could range in shape from near spherical to highly elongate (ratio range of long:short axis 1.1 to 9), the most elongate configuration approximately capturing the surface area to volume ratio of a bird with wings held away from the body;

2) air leaving the lungs was cooled (by counter-current heat exchange) to $5{ }^{\circ} \mathrm{C}$ warmer than air temperature when body temperature was higher than air
Table 1 Endotherm model parameters for the budgerigar/night parrot model, with values specific to the night parrot in brackets

\begin{tabular}{|c|c|c|c|}
\hline Parameter & Units & Value & Source \\
\hline Mass & g & $33.7(100)$ & $\begin{array}{l}{[36]} \\
\text { (this study) }\end{array}$ \\
\hline Core temperature & ${ }^{\circ} \mathrm{C}$ & $38-45$ & {$[36]$} \\
\hline Body length & $\mathrm{mm}$ & $123(138)$ & this study \\
\hline Body width & $\mathrm{mm}$ & $41(45)$ & this study \\
\hline Body depth & $\mathrm{mm}$ & $42(48)$ & this study \\
\hline $\begin{array}{l}\text { Thermal conductivity } \\
\text { of flesh }\end{array}$ & $W m^{-1} C^{-1}$ & $0.412-2.8$ & [39] \\
\hline Flesh density & $\mathrm{kg} \mathrm{m}^{-3}$ & 1000 & assumed \\
\hline $\begin{array}{l}\text { Percent of surface area } \\
\text { that is ventral }\end{array}$ & $\%$ & 30 & estimated \\
\hline $\begin{array}{l}\text { Percent of skin acting } \\
\text { as free water surface }\end{array}$ & $\%$ & $0.05-10$ & estimated \\
\hline$\Delta$ inhaled vs. exhaled air & ${ }^{\circ} \mathrm{C}$ & $5(7.8)$ & $\begin{array}{l}\text { estimated } \\
\text { (this study) }\end{array}$ \\
\hline $\mathrm{O}_{2}$ extraction efficiency & $\%$ & $25-6$ & estimated \\
\hline Configuration factor to sky & $\%$ & 50 & assumed \\
\hline $\begin{array}{l}\text { Configuration factor to } \\
\text { ground }\end{array}$ & $\%$ & 50 & assumed \\
\hline Emissivity & $\%$ & 99 & assumed \\
\hline $\begin{array}{l}\text { Solar reflectivity of dorsal } \\
\text { feathers }\end{array}$ & $\%$ & $(24.8)$ & (this study) \\
\hline $\begin{array}{l}\text { Solar reflectivity of ventral } \\
\text { feathers }\end{array}$ & $\%$ & $(35.1)$ & (this study) \\
\hline $\begin{array}{l}\text { Solar transmissivity of } \\
\text { feathers }\end{array}$ & $\%$ & 0 & assumed \\
\hline $\begin{array}{l}\text { Feather element diameter } \\
\text { dorsal }\end{array}$ & $\mu \mathrm{m}$ & 30.0 & estimated \\
\hline $\begin{array}{l}\text { Feather element diameter } \\
\text { ventral }\end{array}$ & $\mu \mathrm{m}$ & 30.0 & estimated \\
\hline Feather length dorsal & $\mathrm{mm}$ & $23.1(26.4)$ & this study \\
\hline Feather length ventral & $\mathrm{mm}$ & $22.7(25.5)$ & this study \\
\hline Feather depth dorsal & $\mathrm{mm}$ & $5.8(6.6)$ & this study \\
\hline Feather depth ventral & $\mathrm{mm}$ & $5.6(7.2)$ & this study \\
\hline Feather density dorsal & $\mathrm{cm}^{-2}$ & 10,000 & estimated \\
\hline Feather density ventral & $\mathrm{cm}^{-2}$ & 10,000 & estimated \\
\hline Faecal water & $\%$ & 60 & [34] \\
\hline $\begin{array}{l}\text { Food protein per gram } \\
\text { dry food }\end{array}$ & $g$ & 0.12 & [34] \\
\hline $\begin{array}{l}\text { Food lipid per gram } \\
\text { dry food }\end{array}$ & g & 0.04 & [34] \\
\hline $\begin{array}{l}\text { Food carbohydrate per } \\
\text { gram dry food }\end{array}$ & g & 0.53 & [34] \\
\hline Food water content & $\%$ & $10,25,55$ & [34], this study \\
\hline $\begin{array}{l}\text { Digestive efficiency } \\
\text { (of carbohydrate) }\end{array}$ & $\%$ & 90 & {$[34]$} \\
\hline
\end{tabular}


Table 2 Environmental conditions for metabolic chamber simulations

\begin{tabular}{llll}
\hline Variable & Units & Value & Source \\
\hline Air temperature & ${ }^{\circ} \mathrm{C}$ & $0-45$ & {$[36]$} \\
Wind speed & $\mathrm{mm} \mathrm{s}^{-1}$ & $0.64-1.8$ & derived from [36] \\
Relative humidity & $\%$ & $15-20.8$ & {$[39]$} \\
\hline
\end{tabular}

temperature (and otherwise was at body temperature) [see 38];

3) skin thermal conductivity could vary from 0.412 to $2.8 \mathrm{~W} \mathrm{~m}^{-1}{ }^{\circ} \mathrm{C}^{-1}$ (typical range for animal tissue [39]);

4) core temperature could range from $38^{\circ} \mathrm{C}$ to $43{ }^{\circ} \mathrm{C}$;

5) basal metabolic rate varies with mass according to McKechnie and Wolf's [40] allometric equation, with a $\mathrm{Q}_{10}$ response of 2.5 to increased body temperature above $38{ }^{\circ} \mathrm{C}$.

6) oxygen extraction efficiency could vary from $25 \%$ down to $6 \%$ under heat load to simulate observed maximum level of pulmonary water loss;

7) cutaneous water loss could rise under heat load, with the percentage area of the skin area acting as a free water surface ranging from $0.05 \%$ to a maximum of $10 \%$ such that non-pulmonary water loss rose to approximately $70 \%$ of total evaporative water loss [see 41];

To scale this model to the night parrot, we allowed basal metabolic rate to change as expected according to the above-cited allometric equation from a $33 \mathrm{~g}$ bird to a $100 \mathrm{~g}$ bird, based on masses of two individual night parrots captured in April 2015 and May 2016 (S. Murphy, unpubl. data), and changed the plumage characteristics based on museum specimen measurements, above. We also assumed the difference between air temperature and exhaled air was $7.8{ }^{\circ} \mathrm{C}$ to match the observed difference between air and cere temperature in Fig. 1. All other parameters were assumed to be identical to those of the budgerigar.

The simulation started under the assumption of cold conditions, with a spherical posture, low flesh thermal conductivity, base cutaneous water loss and high oxygen extraction efficiency. In field simulations, the parrots were simulated to first seek shelter in Triodia grass hummocks (90\% shade, $0.1 \mathrm{~m} \mathrm{~s}^{-1}$ wind speed, as described further below). In the field and metabolic chamber simulations, parrots under hot conditions were simulated to first change posture and flesh thermal conductivity to the extreme allowable values, then to allow $T_{\mathrm{b}}$ to rise to $41{ }^{\circ} \mathrm{C}$, and finally to increase respiratory and cutaneous water loss rates and core temperature up to the allowable limits; i.e. evaporative heat loss and extreme hyperthermia were simulated as last resorts. Similarly, under cold conditions, elevated metabolic rates were only attempted when postural and flesh conductivity options were exhausted.

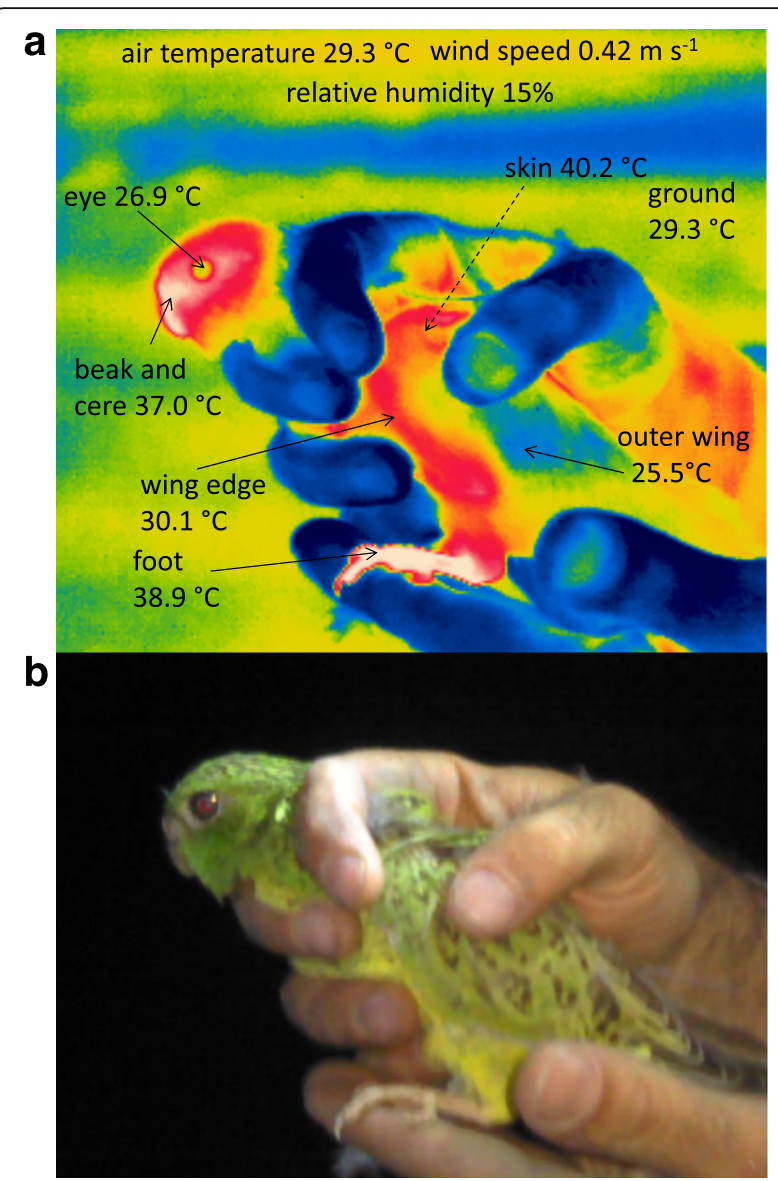

Fig. 1 Long wavelength thermal infra-red (a) and associated visible (b) image of a $102 \mathrm{~g}$ night parrot 5 mins after capture at 18:48 on $6^{\text {th }}$ May 2016. Under the observed microclimatic conditions, assuming a core body temperature of $42.0^{\circ} \mathrm{C}$, the biophysical model predicted a skin temperature of $40.2^{\circ} \mathrm{C}$ and an outer feather temperature of $29.1^{\circ} \mathrm{C}$

\section{Water budget model}

As with the heat budget model, we based the water budget model of the night parrot on that of the budgerigar. Water inputs include drinking water, preformed (dietary) water and metabolic water. The latter varies with diet such that $0.4,1.07$ and $0.56 \mathrm{~g}$ of metabolic water is produced per gram of protein, lipid and carbohydrate metabolised, respectively [42]. Following Cade and Dybas [34] we assumed a diet with a dry mass composition of $12 \%$ protein, $4 \%$ fats and $53 \%$ digestible carbohydrate. Water outputs include urinary, faecal and evaporative losses. Budgerigars fed on dry (10\% water) seed and without drinking water produce faeces with $60 \%$ water or less and no urinary water [34]. Depending on the water vapour pressure deficit, budgerigars can survive indefinitely on dry seed without drinking water at air temperatures between 14 and $20^{\circ} \mathrm{C}$ and can go for long periods with little mass loss at $30{ }^{\circ} \mathrm{C}[34,35]$.

We assumed maximum gross daily energy intake of dry (10\% water) seed scales with basal metabolic rate 
(BMR), and that digestible energy intake is roughly 4.6 times BMR [43]. This produced an estimate of $\approx 10 \mathrm{~g}$ wet food per day for a $33 \mathrm{~g}$ budgerigar, which is consistent with a detailed study of their daily food intake in captivity [44] (mean 6.92, range 1.24-15.47) but lower than that found by Cade and Dybas [34] $(\approx 4 \mathrm{~g})$. The same calculation produced an estimate of $21.8 \mathrm{~g}$ for a $100 \mathrm{~g}$ night parrot. We explored different food water contents, keeping the total mass of food constant, such that a parrot feeding on food with greater than $10 \%$ water content would obtain more preformed water, but less energy, per gram eaten.

In simulations of parrots under natural conditions we considered diets of seed with $10 \%$ water, but also succulent plant leaves with 25 and 55\% water. The latter two figures are based on pre- and post-oven dried masses of two samples of the chenopod Sclerolaena longicuspis. One sample (55\%) was collected from a shallow run-on zone that supported succulent plants, while the other was from an area immediately adjacent to this. In April 2015, a night parrot was observed in close proximity to the run-on zone, leading us to speculate that night parrots may derive substantial dietary water from this (and potentially other) succulent plant species. Based on these diets, we assessed how often parrots would exceed potentially lethal dehydration levels of $11 \%$ and $22 \%$ of body mass, following McKechnie and Wolf [5].

\section{Microclimate model and climate change scenarios}

We modelled microclimates using NicheMapR microclimate model [12]. This model, when applied in Australia using interpolated daily weather data (air temperature, vapour pressure and solar radiation) and a continent-wide soil database as input, was recently shown to reliably predict actual soil temperatures (within 10\% of observed values) across a wide range of environments [45]. We implemented the model as reported in Kearney et al. [45] with the additional incorporation of a daily gridded mean wind speed product [14], assuming maximum wind speed was double, and minimum wind speed was half, the mean value [ 45 used long-term monthly mean values]. We estimated air temperature, wind speed and relative humidity at $4 \mathrm{~cm}$ above the ground either in zero or $90 \%$ shade, to capture environments available to foraging and sheltering parrots, respectively, but assumed that parrots experienced low wind $(0.1 \mathrm{~m} / \mathrm{s})$ when sheltering in Triodia tussocks.

We simulated future climate by imposing projected monthly changes in temperature, humidity, solar radiation and wind speed for 2070 onto interpolated daily weather data following the approach described in Briscoe et al. [32]. Projections were obtained from six Global Circulation Models (GCMs), ACCESS 1.3, ACCESS 1.0, CanESM2, GDFL-CM3, HadGem2-CC and HadGem2-ES, which perform well in capturing past climate in Australia [46].

\section{Results}

\section{Museum specimen measurements}

Plumage measurements are reported in Table 1, with depth averaging $4.9 \mathrm{~mm}$ for the budgerigar and $6.9 \mathrm{~mm}$ for the night parrot, and 20.1 and $26.0 \mathrm{~mm}$, respectively, for feather lengths. The mean solar reflectivity of the night parrot was $30 \%$.

\section{Heat and water budget model}

The endotherm model captured the response of the budgerigar to increasing air temperature, showing close agreement with observed metabolic rate, body temperature and evaporative water loss (Fig. 2). Initially the maximum allowed ratio between the long and short axis of the bird was set to 3 , matching observed dimensions of budgerigars at rest (Table 1), but this resulted in premature increase in evaporative water loss. It was found that a much closer match to the observed data was possible if the surface area to volume ratio was allowed to increase further by allowing the long to short axis ratio to extend to 9, which we presume accounts for the birds holding their wings away from their body. The model also predicted that budgerigars would remain in positive water balance on a diet of dry seed only up to an air temperature of $14.5{ }^{\circ} \mathrm{C}$, consistent with Weathers and Schoenbaechler [36]. This threshold air temperature would rise to $19.5{ }^{\circ} \mathrm{C}$ under a more typical indoor humidity level of 50\% (a vapour pressure deficit based on a humidity of $15 \%$ was assumed at this temperature in the original simulation, Table 2).

Converting the budgerigar model to the night parrot (from $33 \mathrm{~g}$ to $100 \mathrm{~g}$, increasing the plumage depth by the observed amount, allometrically adjusting the basal metabolic rate) resulted in a reduction of the lower critical temperature from 27.5 to $24.5{ }^{\circ} \mathrm{C}$, a shift in the onset of the evaporative cooling response from an air temperature of 32.5 to $30.5{ }^{\circ} \mathrm{C}$, and a reduction of the maximum massspecific water loss rate by approximately $30 \%$ (Fig. 2). The model predictions were consistent with observed skin $\left(40.2{ }^{\circ} \mathrm{C}\right.$ ) and outer feather temperature (mean $\approx 28{ }^{\circ} \mathrm{C}$ ) of a night parrot photographed with a long wavelength thermal infrared camera under known environmental conditions (Fig. 1) under the assumption of a body temperature of $42{ }^{\circ} \mathrm{C}$, rather than the assumed minimum value of $38^{\circ} \mathrm{C}$. The photo was taken 5 min after capture and the bird was flying at the time of capture, all of which is consistent with the inferred higher body temperature.

\section{Microclimate observations and predictions}

Shaded air temperatures extracted for the study site from the continental $5 \mathrm{~km}$ weather grids were consistently $1.5^{\circ} \mathrm{C}$ lower than both the shaded air temperatures measured with the iButtons in trees (Fig. 2a,b) and the air temperatures recorded by the on-site weather station, consistent with error estimates of the weather grids for this region [13]. Thus, all 

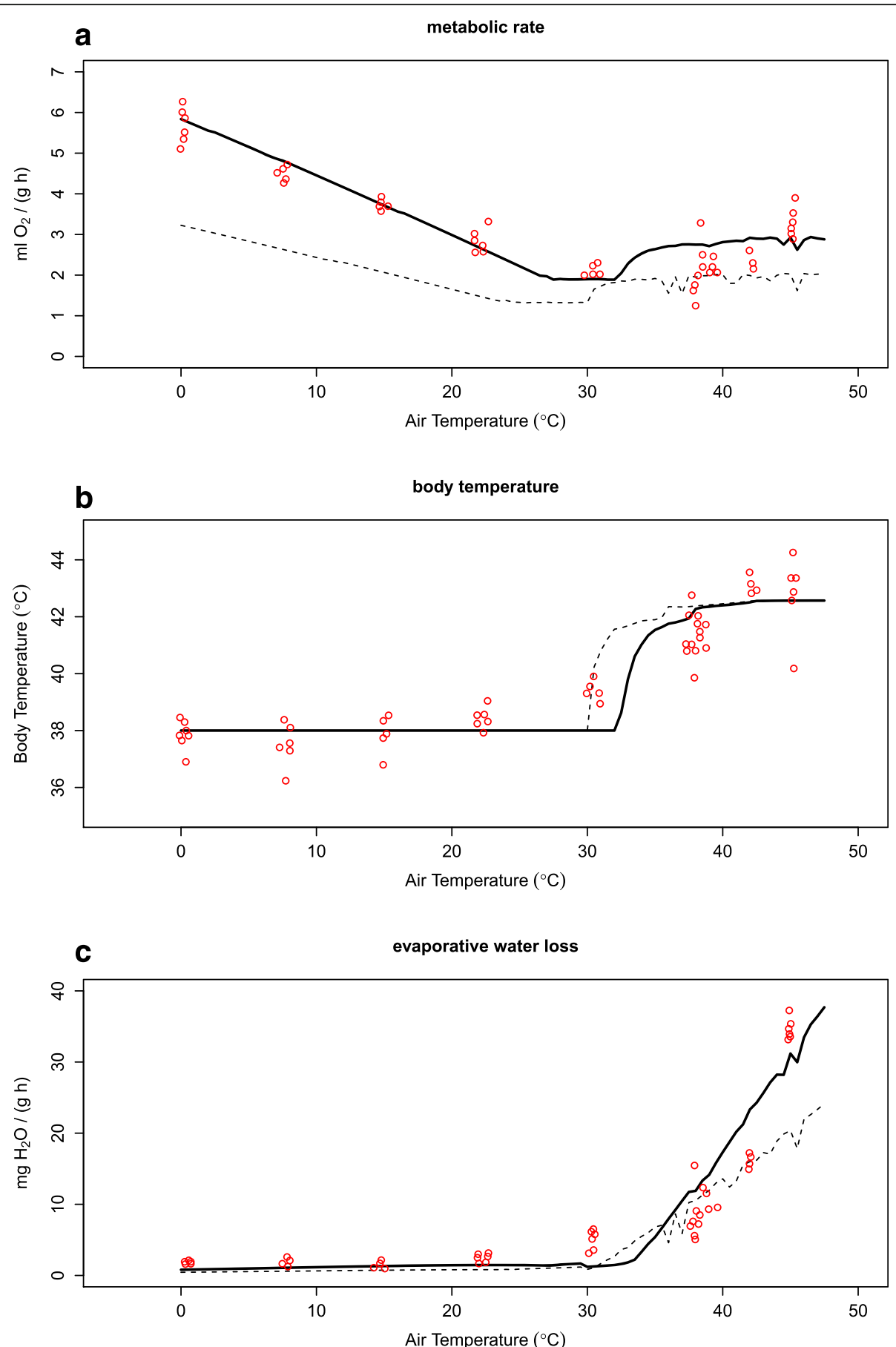

Fig. 2 Observed a metabolic rate, $\mathbf{b}$ body temperature and $\mathbf{c}$ evaporative water loss rate of budgerigars in response to increasing temperature (adapted from Weathers and Schoenbaechler [36]) (red dots) compared to model predictions for the budgerigar (solid black line) and the night parrot (dashed black line)

predictions presented in this study are based on $+1.5{ }^{\circ} \mathrm{C}$ adjusted air temperatures. With this adjustment, predicted hourly air temperatures at $1.2 \mathrm{~m}$ showed good general agreement with the observed values (Fig. 3a,b \& Additional file 1: Figure S2). The main discrepancy with the $1.2 \mathrm{~m}$ air temperature predictions was for daily minima to be underestimated (Additional file 1: Figure S2), possibly reflecting cold air drainage from the surrounding hills (mesas) [47]. Predictions of the two iButton shaded air temperature measurements in trees (Fig. 3a,b) showed correlation coefficients $(r)$ of 0.82 and 0.83 , and root mean squared deviations (rmsd) of 3.7 and $4.1{ }^{\circ} \mathrm{C}$, respectively. 


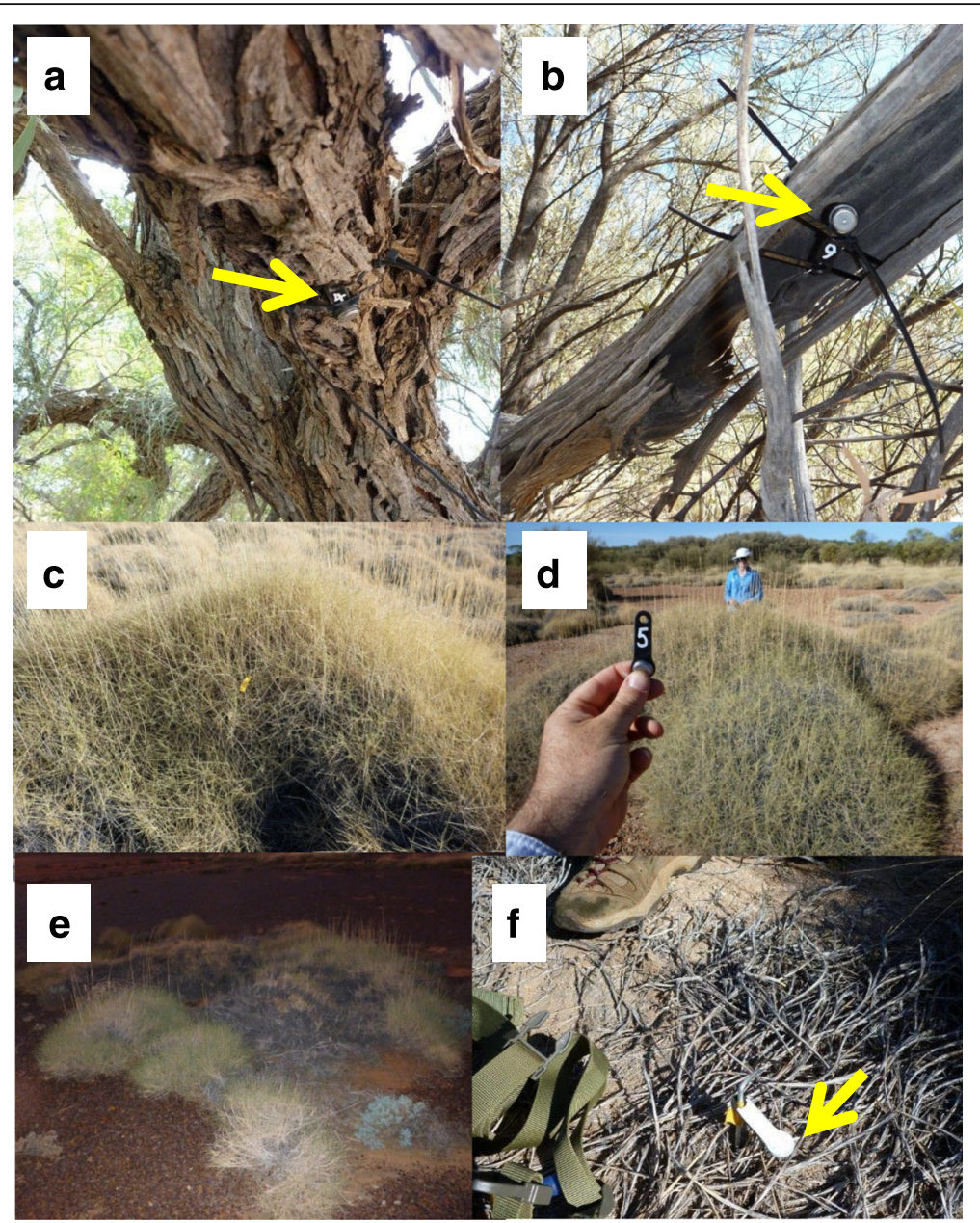

Fig. 3 Locations of temperature data loggers in the habitat of the night parrot, measuring: a-b shaded air temperature at approximately $1.2 \mathrm{~m}$ in trees, $\mathbf{c}-\mathbf{d}$ temperature $4 \mathrm{~cm}$ above the ground in centre of large Triodia tussocks potentially available to night parrots as roosts, e temperature in tunnel of Autumn Triodia roost, $\mathbf{f}$ temperature near the ground representing the experienced temperature of a foraging night parrot

Temperatures in the two large Triodia clumps (Fig. 2c,d) ranged from between 20 and $47{ }^{\circ} \mathrm{C}$ (Fig. 3c,d). This variation was significantly underestimated when the microclimate model was run under the assumption of $90 \%$ shade and $4 \mathrm{~cm}$ above the ground, but showed close agreement when assuming $70 \%$ shade at this same height (Fig. 3c,d), both showing correlations of 0.81 , and rmsd of 4.1 and $4.3{ }^{\circ} \mathrm{C}$, respectively. In the night parrot simulations, however, we conservatively assumed $90 \%$ shade as some disturbance of the Triodia necessarily occurs when inserting the data loggers, and the parrots may be able to choose particularly dense locations and/or modify the leaves to form roosting structures that would increase shade. Temperatures in the autumn roost site (Fig. 2e) were much higher than those in the larger Triodia clumps (up to $55^{\circ} \mathrm{C}$ ) and were closely approximated by the microclimate model predictions for air temperature at $4 \mathrm{~cm}$ above the ground in full sun $\left(\mathrm{r}=0.83, \mathrm{rmsd}=4.6^{\circ} \mathrm{C}\right)$. Finally, the amplitude of fluctuations in the temperature of a data logger in the open at $4 \mathrm{~cm}$ above the ground (Fig. 2f) was underestimated by the microclimate model predictions of air temperature in the open at the same height. However this logger was directly exposed to solar radiation and, while painted white to minimise solar influences, its temperature was well approximated (Fig. 3f) by simulating a $5 \mathrm{~g}$ cylindrical object absorbing $70 \%$ of the solar radiation $\left(r=0.89, \mathrm{rmsd}=5.7^{\circ} \mathrm{C}\right)$.

Relative humidity (Additional file 2: Figure S3) and wind speed (Additional file 1: Figure S2) were also adequately captured by the microclimate model, although the model tended to underestimate the maximum relative humidity and to overestimate the minimum wind speed.

\section{Historical simulations under field conditions}

Simulations of the year 2015 imply that air temperatures in large Triodia clumps providing $90 \%$ shade would regularly exceed $38{ }^{\circ} \mathrm{C}$ through the warmer months of November through to March, often approaching or slightly exceeding 
$45^{\circ} \mathrm{C}$ (Fig. 5a). Over the same period, predicted ground surface temperature and air temperature in the open exceeded these conditions by 5 to $20{ }^{\circ} \mathrm{C}$ (Fig. 5a). Throughout the same warm months, the biophysical model of the night parrot predicted birds to be elevating core temperature regularly, and that in the cool months the feathers would provide strong insulation against cold conditions (gradients from feather to skin temperature of around $30{ }^{\circ} \mathrm{C}$, Fig. $5 \mathrm{~b}$ ). Deep (90\%) shade would be required during the day to avoid heat stress on all but a few winter days, when shade levels down to $60 \%$ were adequate (results not shown).

Assuming a maximum intake of $21.8 \mathrm{~g}$ food per day, night parrots would always be in positive energy balance with over $200 \mathrm{~kJ}$ excess (discretionary) energy per day when feeding on seeds with $10 \%$ water, down to around $50 \mathrm{~kJ}$ per day when feeding on food of the same energy value per gram of dry mass but with $55 \%$ water (Fig. 5c).

Evaporative cooling was required at rates of over 1-2 g per hour through the warmer months from October through to early April (Fig. 5d). This put the birds into negative daily water balance throughout this period if a diet of seed (10\% water) was assumed, and to a lesser extent if the food was assumed to be $25 \%$ water, with a diet of $55 \%$ water causing negative water balances only occasionally (Fig. 5e). Parrots would regularly be in danger of dehydrating by $11 \%$ of their original body mass each day on a diet of seed only, but could substantially reduce this by feeding on food containing $25 \%$ water, and eliminate it with foods containing 55\% water (Fig 5e). They would be at close to neutral daily water balance from mid-April through to the end of August on a diet of seed, with substantial discretionary water available (e.g. for reproduction) during these months when feeding on moister food (Fig. 5e).

Calculations of cumulative water balance, permitting rehydration with rainfall events greater than $1 \mathrm{~mm}$, substantially exceeded $22 \%$ dehydration in the summer months on a diet of dry seed (Fig. 5f). However, dehydration stayed almost entirely below $22 \%$ on a diet of $25 \%$ water, and never exceeded $11 \%$ on a diet of $55 \%$ water (Fig. 5 f).

Over the summers of $1996 / 7$ to $2014 / 15$, parrots eating only dry seed would have regularly experienced daily dehydration exceeding $11 \%$ for periods of 10 or more days per year, with some exposure to this level of dehydration on a diet of $25 \%$ water (Fig. 6a). However, daily dehydration only exceeded $22 \%$ on a dry seed diet in five of the 19 years. In contrast, cumulative dehydration exceeded $11 \%$ and $22 \%$ in all years on a diet of dry seed (Fig. 6c,d). However, $22 \%$ dehydration was never exceeded on a diet of $55 \%$ water (Fig. $6 \mathrm{~b}$ ).

\section{Climate change projections}

Both maximum and minimum air temperatures are expected to rise approximately $2.9{ }^{\circ} \mathrm{C}$ (range 2.4 to $3.3{ }^{\circ} \mathrm{C}$ ) at the study site by 2070 , with minor or inconsistent change predicted in relative humidity, wind speed and solar radiation (Table 3, Additional file 3: Figure S8, Additional file 4: FigureS9, Additional file 5: Figure S10, Additional file 6: Figure S11). While all six GCMs consistently predicted a small decline (mean 7\%) in annual rainfall, four predicted an increase in summer rainfall with an overall mean projected increase in summer rainfall of 12\% (Table 3, Additional file 7: Figure S12).

Calculations of the water budget for 2015 under the six climate change scenarios for 2070 produced similar estimates of water stress indices (Table 4). When we recalculated the water budget after imposing the ACCESS 1.32070 scenario changes on the historical climate (Additional file 8: Figure S5), daily dehydration levels exceeded $11 \%$ in almost all years irrespective of diet (Fig. 6e), and exceeded $22 \%$ on a diet of seed, and even occasionally on a diet of $55 \%$ water (Fig. 6f). Similarly, cumulative dehydration exceeded the $11 \%$ threshold every year irrespective of diet (Fig. 6g) and exceeded $22 \%$ every year on dry seed and $25 \%$ water diets (Fig. 6h). The $22 \%$ threshold was exceeded on 13 of the 19 years even on the $55 \%$ water diet (Fig. 6h).

\section{Discussion}

\section{Inferring the ecophysiology of the night parrot}

The amount of data required to develop a detailed mechanistic model of a species' climatic niche is not trivial [48, 49]. Some endangered species are sufficiently well studied in this regard, through captive populations and detailed field studies (e.g. [50]). However, in the case of a datapoor, cryptic species like the night parrot, one must make inferences for many parameters based on phylogenetically closely-related and/or ecologically similar species.

In this case we chose to develop a model to compute the thermal and hydric responses of a related, aridadapted species for which extensive data were available the budgerigar - and then adjusted it to the specific known details of the night parrot. In fact, the key parameters

Table 3 Climate change scenarios for the study site in 2070 for minimum $\left(\Delta \mathrm{T}_{\min },{ }^{\circ} \mathrm{C}\right)$ and maximum $\left(\Delta \mathrm{T}_{\max }{ }^{\circ} \mathrm{C}\right)$ air temperature, relative humidity $(\Delta \mathrm{RH}, \%)$, wind speed (\% Wind), solar radiation (\% Solar), annual rainfall (\% ARain) and summer rainfall (\% SRain)

\begin{tabular}{lccccccc}
\hline Scenario & $\Delta \mathrm{T}_{\max }$ & $\Delta \mathrm{T}_{\min }$ & $\Delta \mathrm{RH}$ & \% Wind & \% Solar & \% ARain & \% SRain \\
\hline Access 1.3 & 3.2 & 2.9 & -3.5 & -1.4 & 0.2 & -4.0 & 35.2 \\
Access 1.0 & 2.8 & 3.0 & -1.5 & 1.4 & 0.0 & -0.4 & 18.7 \\
CanESM2 & 3.3 & 2.9 & -1.3 & -2.5 & 0.5 & -9.6 & 4.3 \\
GDFLCM3 & 3.0 & 3.0 & -4.5 & 3.5 & 1.7 & -11.4 & -4.6 \\
HadGEM2-CC & 2.6 & 2.7 & -1.6 & 1.7 & -0.7 & -12.7 & 21.8 \\
HadGEM2-ES & 2.6 & 2.4 & -1.3 & -6.1 & 0.6 & -3.2 & -4.0 \\
mean & 2.9 & 2.8 & -2.3 & -0.6 & 0.4 & -6.9 & 11.9 \\
\hline Air
\end{tabular}

Air temperature and relative humidity are expressed as absolute change while wind speed, solar radiation and rainfall are expressed as percent change 
Table 4 Water stress indices under six different climate change scenarios for the year 2015

\begin{tabular}{|c|c|c|c|c|c|c|}
\hline \multirow[b]{2}{*}{ Scenario } & \multicolumn{3}{|c|}{$11 \%$ dehydration } & \multicolumn{3}{|c|}{$22 \%$ dehydration } \\
\hline & $10 \% \mathrm{H}_{2} \mathrm{O}$ & $25 \% \mathrm{H}_{2} \mathrm{O}$ & $55 \% \mathrm{H}_{2} \mathrm{O}$ & $10 \% \mathrm{H}_{2} \mathrm{O}$ & $25 \% \mathrm{H}_{2} \mathrm{O}$ & $55 \% \mathrm{H}_{2} \mathrm{O}$ \\
\hline \multicolumn{7}{|c|}{ a) Days exceeding 11 or $22 \%$ daily dehydration } \\
\hline Current & 75 & 9 & 0 & 0 & 0 & 0 \\
\hline Access 1.3 & 141 & 71 & 13 & 20 & 3 & 0 \\
\hline Access 1.0 & 144 & 72 & 9 & 16 & 1 & 0 \\
\hline CanESM2 & 150 & 75 & 8 & 20 & 0 & 0 \\
\hline GDFLCM3 & 140 & 85 & 17 & 24 & 4 & 0 \\
\hline HadGEM2-CC & 140 & 61 & 5 & 14 & 0 & 0 \\
\hline HadGEM2-ES & 147 & 66 & 10 & 20 & 0 & 0 \\
\hline \multicolumn{7}{|c|}{ b) Number of events exceeding 11 or $22 \%$ cumulative dehydration } \\
\hline Current & 15 & 14 & 0 & 14 & 3 & 0 \\
\hline Access 1.3 & 20 & 20 & 14 & 20 & 14 & 5 \\
\hline Access 1.0 & 16 & 16 & 9 & 15 & 15 & 3 \\
\hline CanESM2 & 16 & 12 & 11 & 14 & 16 & 3 \\
\hline GDFLCM3 & 14 & 15 & 14 & 15 & 16 & 7 \\
\hline HadGEM2-CC & 13 & 16 & 10 & 15 & 13 & 1 \\
\hline HadGEM2-ES & 15 & 15 & 10 & 13 & 17 & 4 \\
\hline \multicolumn{7}{|c|}{ c) Maximum run of days exceeding 11 or $22 \%$ cumulative dehydration } \\
\hline Current & 38 & 12 & 0 & 16 & 2 & 0 \\
\hline Access 1.3 & 38 & 18 & 7 & 18 & 15 & 5 \\
\hline Access 1.0 & 39 & 18 & 7 & 20 & 10 & 3 \\
\hline CanESM2 & 39 & 25 & 10 & 25 & 12 & 2 \\
\hline GDFLCM3 & 45 & 24 & 10 & 24 & 17 & 5 \\
\hline HadGEM2-CC & 39 & 18 & 9 & 18 & 11 & 1 \\
\hline HadGEM2-ES & 39 & 28 & 10 & 28 & 12 & 5 \\
\hline
\end{tabular}

needed to develop the budgerigar heat balance model were relatively few - the most important being its mass, shape, plumage depth, core body temperature range and basal metabolic rate. The first three morphological traits are easily measured, body temperature is highly phylogenetically conserved in birds [37], and metabolic rate scales predictably with body size [51] and body temperature [52]. The role of feathers in the heat transfer of birds is complex, especially with respect to the role of solar radiation [5]. However, the nocturnal habit of the night parrot renders our predictions less sensitive to these complexities. Where having detailed data on thermal responses is most important is in determining the particular responses to heat and cold stress that the animal exhibits, and in what order. The detailed data on the physiological response of the budgerigar allowed us to infer this sequence of responses (as described in the Methods section), which is typical of desert-adapted birds [53] in the delayed onset of evaporative cooling. Our final model showed close agreement with the observed metabolic, body temperature and evaporative water loss responses of the budgerigar between air temperatures of 0 to $45^{\circ} \mathrm{C}$ (Fig. 2).

As expected, scaling the budgerigar up to the size of a night parrot shifted the thermoneutral to lower temperatures and resulted in reduced mass-specific evaporative water loss rates (Fig. 2). The reduced mass-specific water loss rate would make the night parrot more robust than the budgerigar to desiccation under short-term exposures to high temperature [see 5]. Our calculations of the water budget of the night parrot again relied on inferences about its water economy from the budgerigar, specifically its faecal water content. Although the budgerigar exhibits relatively high levels of water conservation among birds [53], it is possible that the night parrot exhibits more extreme adaptations. For example, it has an unusually large cere [22] relative to other parrots, which may relate to its ability to save water by pre-cooling exhaled air [54]. Conversely, they also have an unusually large eye (Fig. 1), presumably related to their nocturnal habit, which may exacerbate water loss. 


\section{Microclimates available to the night parrot}

Half the challenge of biophysical modelling is the accurate estimation of microclimates available to organisms. However, recent developments in the availability of gridded climate products for Australia [13, 14], and developments in microclimate modelling software [12], now make it possible to infer microclimates from continent-scale datasets with sufficient accuracy for biophysical calculations [45]. In the present case, the downscaling of the gridded daily weather data to hourly microclimatic conditions was largely successful, with good agreement between observed and predicted hourly variation in air temperature, wind speed and relative humidity (Fig. 4, Additional file 9: Figure S1 \& Additional file 1: Figure S2).

Most importantly, the modelling system captured hourly variation in the thermal environment inside potential roosts of the night parrot to within $\pm 4{ }^{\circ} \mathrm{C}$, or within $15 \%$ of the measured range (Fig. 4c,d). The main discrepancies included a downward bias of $1.5^{\circ} \mathrm{C}$ in the raw gridded air temperatures (for which we corrected), and a tendency to underestimate maximum humidity and minimum air temperatures at night time, potentially due to meso-scale climatic factors such as cold air drainage. These inaccuracies would not influence our main conclusions since the most important aspect of our calculations relate to heat stress during the day when air temperature and relative humidity estimates were more accurate.

\section{The water budget of the night parrot}

Our calculations of the water and energy budget of the night parrot are likely to be conservative for two main reasons. First, we have assumed no additional heat or water costs for activity, instead assuming metabolic rate will only vary from basal due to the effects of body temperature and the need for metabolic heating in the cold. In relation to cold, the higher metabolic rates due to activity would, to some extent, cover the heating requirements of the parrot (metabolic heat substitution [55]). Moreover, during the heat of the day in warm weather, many arid-adapted birds such as the budgerigar conserve water by remaining inactive [53], and thus would be near basal metabolic rate as we assumed. Nonetheless, tracking studies of the night parrot (S. Murphy et al., in prep.) indicate that it can move tens of kilometres a night to feed and drink, and future work will need to incorporate the associated costs into a more complete energy and water budget.

Second, we assumed that night parrots were able to obtain the allometrically-inferred maximum daily food intake rate of $21.8 \mathrm{~g}$ of food per $100 \mathrm{~g}$ bird. Food availability is currently unknown at the site and is likely to vary with the highly erratic inter-annual rainfall that occurs here and throughout the known range of the species.

Despite our conservative assumptions about activity costs and food availability, and our assumption that parrots can shelter in 90\% shade (measured temperatures in large Triodia clumps better matched model predictions for $70 \%$ shade, Fig. 3), simulated water costs for the night parrot at the study site under historical conditions were very high (Fig. 5d-f \& 6a-d). In our simulation of the year 2015, water loss rates often exceeded $2 \mathrm{~g}$ per hour (Fig. $5 \mathrm{~d}$ ) and parrots would be expected to regularly lose in excess of $11 \%$ of their body mass as water while inactive during the day in summer if feeding solely on seed (Fig. 5e). Such a scenario would necessitate nightly drinking, because otherwise cumulative dehydration would exceed the likely lethal threshold of $22 \%$ multiple times through the year (Fig. 5f). In contrast, with access to food of high water content (55\%), our calculations imply that night parrots could have persisted without drinking. Extension of these calculations 20 years into the past, however, shows that 2015 was a relatively mild year (Additional file 10: Figure S4); in some years (summers of 2006/7 and 2013/14) daily dehydration could have exceeded $22 \%$ on a seed only diet (Fig. 6b) and cumulative dehydration could have exceeded $11 \%$ in some years, even on a diet of $55 \%$ water content (Fig. 6c).

One of the most effective behavioural options for thermal buffering is to shelter below ground [56], an option not available to most desert birds [53]. There are anecdotes of night parrots sheltering in rabbit burrows [18], caves [57] and even tunnels dug into sand [58]. To assess the potential significance of burrowing, we ran simulations assuming that inactive night parrots shelter $10 \mathrm{~cm}$ below ground in the shade (Additional file 11: Figure S6 \& Additional file 12: Figure S7). This dramatically reduced water requirements, to the extent that the parrots could survive on seed-only diets without exceeding $22 \%$ dehydration, and rarely exceeding $11 \%$ dehydration, considering both daily and cumulative water requirements (Fig. 6S). This is an aspect worthy of attention in future field studies of the species.

\section{Climate change projections for the night parrot's water budget}

The projected climate warming of approximately $3{ }^{\circ} \mathrm{C}$ by 2070 at the study site had striking impacts on the expected water budget (Fig. 6 and Additional file 10: Figure S4, Table 4). For example, this led to an increase in the frequency of daily dehydration events exceeding $11 \%$ from 75 days per year to around 144 on a diet of seed, irrespective of the climate change scenario (Table 4a). The proportional increase was even greater when food water content was increased to $25 \%$, increasing from 9 to around 72 days per year, and changed from no events to around 10 events per year under the $55 \%$ water diet. The mean air temperature at the site in 2015 was $25.2^{\circ} \mathrm{C}$, thus an $11.5 \%$ increase in temperature imposed a $200-800 \%$ increase in the frequency of stress events. The 11 and $22 \%$ dehydration thresholds would even be exceeded under the 

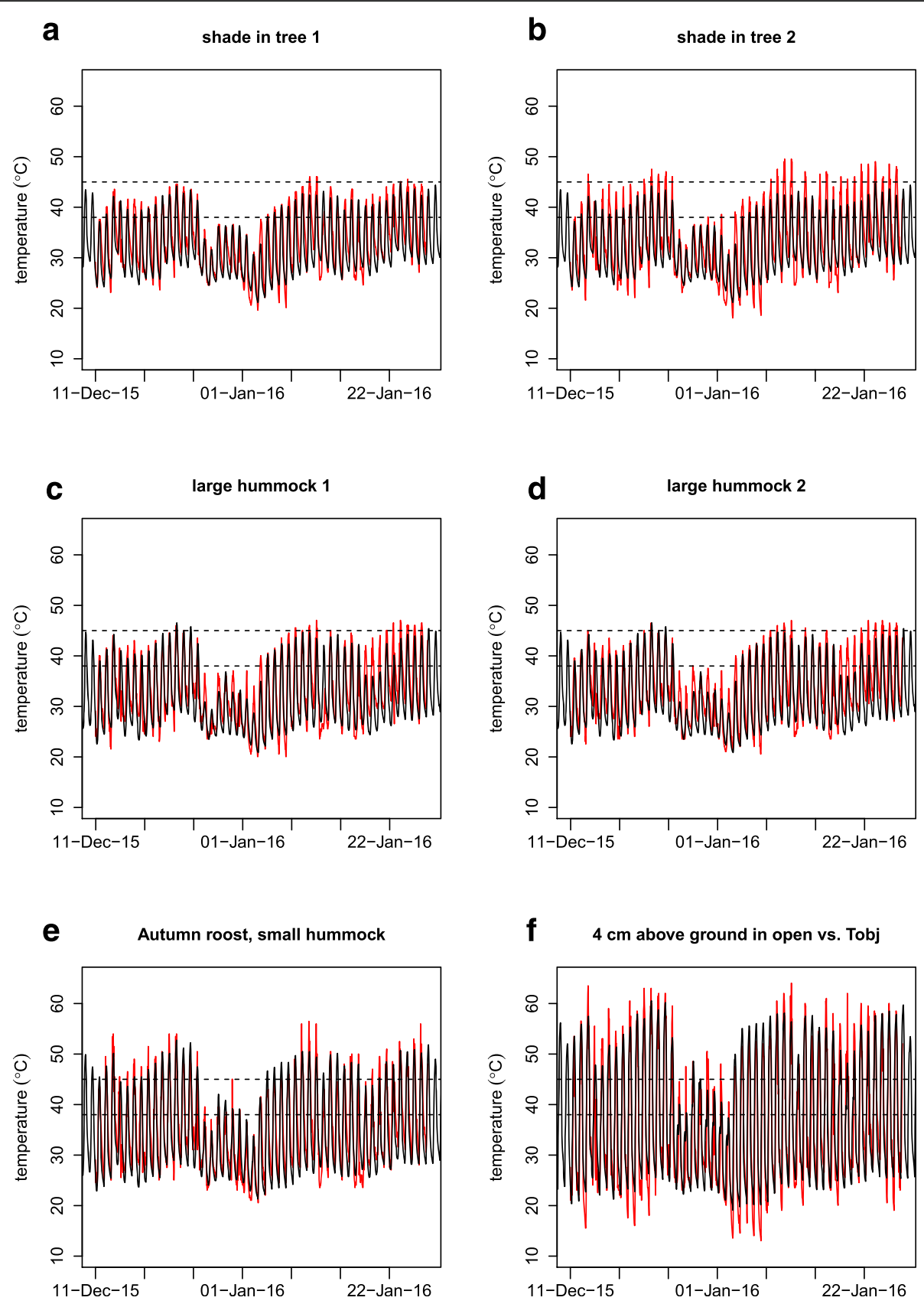

Fig. 4 Observed temperature in night parrot habitat (red lines) compared to microclimate model predictions driven by historical gridded daily weather data (black lines). Logger locations are depicted in Fig. 3: a-b shaded air temperature at approximately $1.2 \mathrm{~m}$ in trees, $\mathbf{c}-\mathbf{d}$ temperature 4 $\mathrm{cm}$ above the ground in centre of large Triodia tussocks potentially available to night parrots as roosts, e temperature in tunnel of Autumn Triodia roost, $\mathbf{f}$ temperature near the ground representing the experienced temperature of a foraging night parrot

assumption of a burrowing habit (Additional file 12: Figure S7). The reason for such non-linear and threshold responses to warming is easily seen in the sudden and steep rise in evaporative water loss rate as environmental temperature approaches body temperature (Fig. 2c).

There was an overall decline in projected rainfall across all climate models which would act to reduce available standing water and food water content (Table 3). There was a minor tendency towards increased summer rainfall at the site (Table 3, Additional file 7: Figure S12) which may partially offset the negative impacts of increased air temperatures, but overall the greater evaporative power of the environment under a $3{ }^{\circ} \mathrm{C}$ warming will likely lead to lower water availability for the parrots.

Our predictions indicate that climate change will impose a substantial increase in the risk of heat wave induced die- 

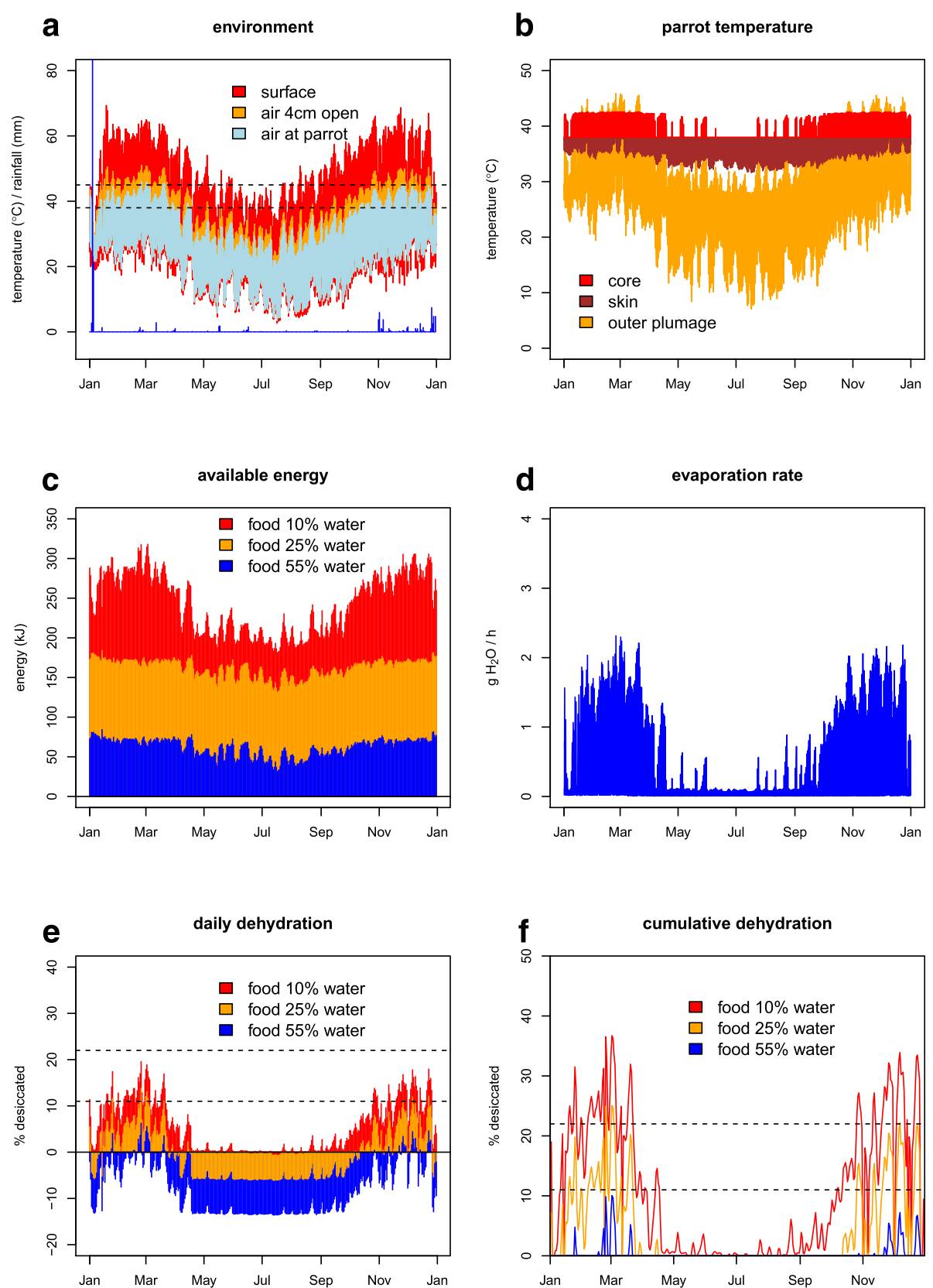

Fig. 5 Calculations of night parrot environmental conditions and thermal, hydric and energetic state in 2015 at the study site: a hourly soil surface temperature (red), $4 \mathrm{~cm}$ air temperature in the open (orange) and experienced air temperature (light blue - either in the open or in the shade or in between, depending on the simulated behaviour of the parrot), with dashed horizontal lines indicating $38^{\circ} \mathrm{C}$ (resting core body temperature) and $45^{\circ} \mathrm{C}$ (near lethal body temperature), and vertical blue lines indicating rainfall $(\mathrm{mm})$; $\mathbf{b}$ hourly parrot core temperature (bright red), skin temperature (dark red) and outer feather temperature (orange); c hourly discretionary energy (assimilated energy minus maintenance costs) when feeding at maximal simulated intake on seed (red), succulents with $25 \%$ water (orange) and succulents with $55 \%$ water (blue); $\mathbf{d}$ hourly evaporative water loss rate; e daily percentage body mass of water lost (i.e. negative values represent discretionary water); $\mathbf{f}$ daily cumulative dehydration, with rainfall events $>1 \mathrm{~mm}$ permitting complete rehydration on a given day

off events of the sort summarised by McKechnie and Wolf $[5,8]$. The ability of the night parrot to survive such events will depend critically on the number and distribution of other populations and the connectivity between them, of which virtually nothing is presently known. It will also be strongly influenced by the extent to which they use subterranean retreats (Additional file 12: Figure S7). 

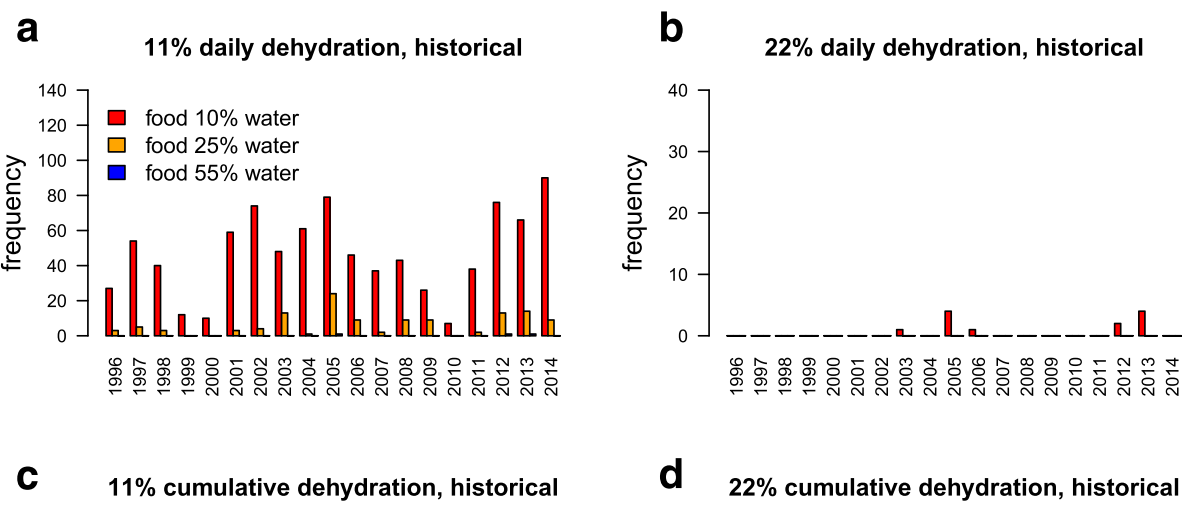

d $22 \%$ cumulative dehydration, historical
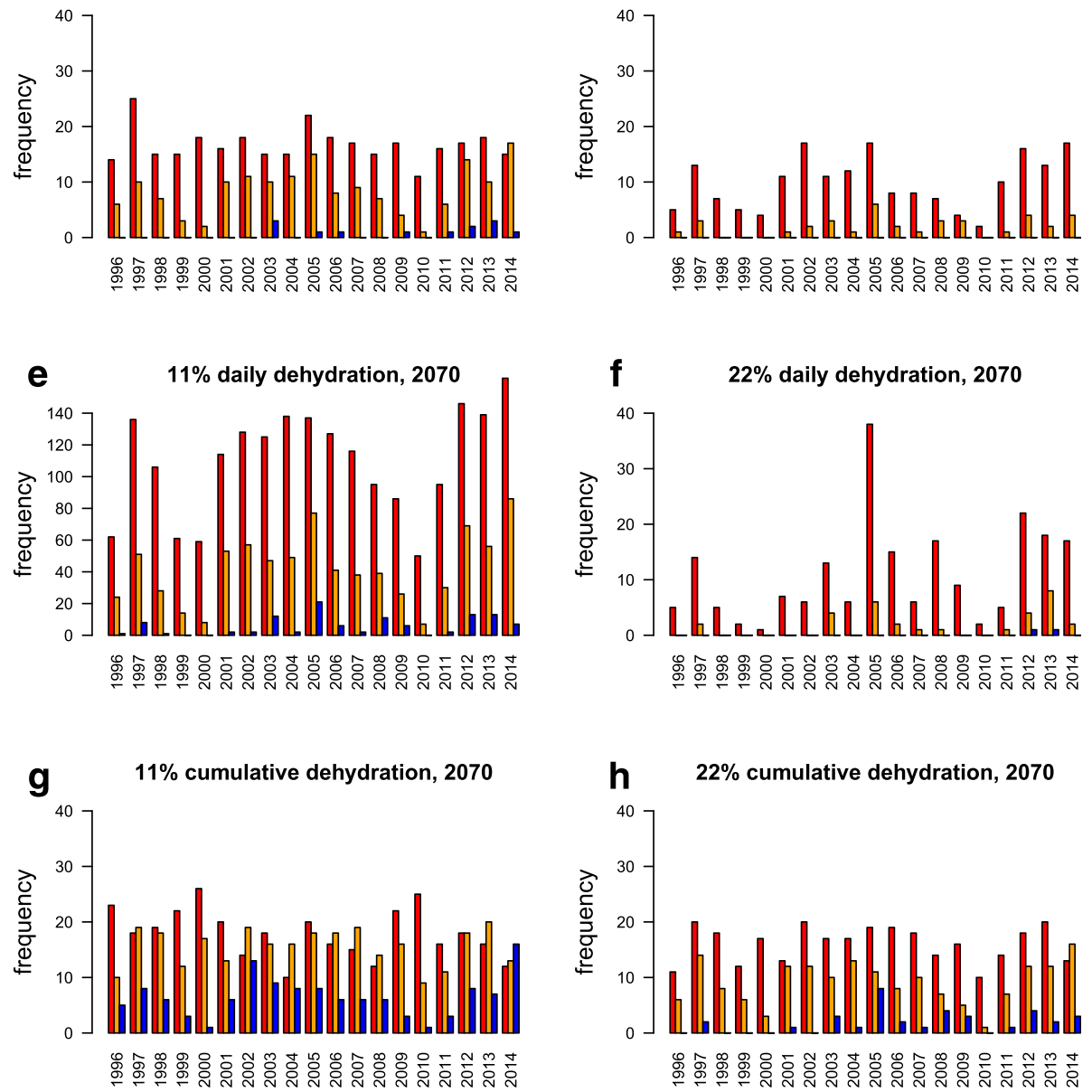

Fig. $\mathbf{6}$ The frequency that daily $(\mathbf{a}, \mathbf{b}, \mathbf{e}, \mathbf{f})$ or cumulative $(\mathbf{c}, \mathbf{d}, \mathbf{g}, \mathbf{h})$ dehydration of night parrots was predicted to exceed $11 \%(\mathbf{a}, \mathbf{c}, \mathbf{e}, \mathbf{g})$ or $22 \%$ (b, d, f, h) over the summers 1996/7 to 2014/15 at the site under historical (a-d) and projected (e-h, 2070 ACCESS 1.3) climate

\section{Extending the model}

The calculations presented here could be extended to capture life history and phenological aspects of the night parrot as influenced by climate. For example, reproductive potential could be computed $[32,59]$ based on estimates of egg energy and water content from measurements of egg dimensions and literature on typical values for related birds [60]. General models of growth and reproduction such as the Dynamic Energy Budget model [e.g. 49, 61] could also be developed based on life history observations of the closely related ground parrot Pezoporus wallacus. Such calculations could then be integrated with estimates of water availability on the basis of soil moisture and standing water availability $[12,50]$ to derive a more complete, whole life-cycle perspective on the impact of climate change and variability on this species of the sort envisioned by McKechnie and Wolf [8]. 


\section{Conclusions}

Conservation management of endotherms requires an understanding of how climate change may affect threatened and endangered species, especially in the context of other pressures like habitat modification and feral predators. Here we have illustrated how the methods of biophysical ecology can provide insight into the water budget of an endangered species under different climate scenarios. Our analysis predicts strong associations between the night parrot and succulent vegetation in the absence of standing water, points to a large advantage of subterranean retreats, and highlights heat-induced water stress as a major issue for the future of this species.

Effective predictions of heat stress in birds can be made directly from empirical approaches of estimating thermal responses to heat [5], but such predictions assume conditions similar to metabolic chambers and are therefore less robust. Mechanistic approaches are also more likely to suggest new avenues for research, by allowing hypothetical scenarios to be explored as exemplified by our calculations of the consequences of burrowing for the night parrot's water budget. The generality of the modelling approach means it can be easily transferred to other taxa, the microclimate and endotherm models used here having been applied to a wide range of other taxa [e.g. 32, 59].

The ability to approximate microclimate conditions relevant to night parrots (and other animals) from continent-wide grids provides the potential to make the kinds of calculations illustrated here over much broader scales of space and time. This will allow predictions of the relative suitability of different parts of Australia for night parrots in recent history, under different scenarios of habitat quality, and thereby inform future survey work for new populations.

\section{Additional files}

Additional file 1: Figure S2. Predicted (black) hourly wind speed (a) and air temperature (b) at the site compared to observations from the weather station (red) and, in late 2015 (green) the shaded $1.2 \mathrm{~m}$ air temperature measurements from data loggers in trees as depicted in Fig. 3a \& b. (PDF $1117 \mathrm{~kb}$ )

Additional file 2: Figure S3. Observed relative humidity in night parrot habitat (red lines) compared to microclimate model predictions driven by historical gridded daily weather data (black lines). Logger locations are depicted in Fig. 3. (PDF 289 kb)

Additional file 3: Figure S8. Predicted absolute monthly changes in minimum (blue) and maximum (red) air temperature at the study site under six different Global Circulation Models. (PDF 142 kb)

Additional file 4: Figure S9. Predicted absolute monthly changes in relative humidity at the study site under six different Global Circulation Models. (PDF $125 \mathrm{~kb}$ )

Additional file 5: Figure S10. Predicted proportional monthly changes in wind speed at the study site under six different Global Circulation Models. (PDF $129 \mathrm{~kb}$ )
Additional file 6: Figure S11. Predicted proportional monthly changes in solar radiation at the study site under six different Global Circulation Models. (PDF $133 \mathrm{~kb}$ )

Additional file 7: Figure S12. Predicted proportional monthly changes in rainfall at the study site under six different Global Circulation Models. (PDF $137 \mathrm{~kb}$ )

Additional file 8: Figure S5. Predicted thermal conditions and hydric state of the night parrot at the study site from 1996-2015 under the ACCESS 1.3 global circulation model 2070 climate change scenario: a) maximum daily soil surface temperature (red), $4 \mathrm{~cm}$ air temperature in the open (orange) and experienced air temperature (light blue - either in the open or in the shade or in between, depending on the simulated behaviour of the parrot), with dashed horizontal lines indicating $38^{\circ} \mathrm{C}$ (resting core body temperature) and $45^{\circ} \mathrm{C}$ (near lethal body temperature), and vertical blue lines indicating rainfall $(\mathrm{mm}) ; \mathrm{b}$ ) daily maximum percent dehydration; c) daily cumulative dehydration, with rainfall events $>1 \mathrm{~mm}$ permitting complete rehydration on a given day. (PDF 357 kb)

Additional file 9: Figure S1. Solar reflectivity across the wavelengths 300-2100 nm for two specimens of the night parrot. (PDF $63 \mathrm{~kb}$ )

Additional file 10: Figure S4. Predicted thermal conditions and hydric state of the night parrot at the study site from 1996-2015 under current climate: a) maximum daily soil surface temperature (red), $4 \mathrm{~cm}$ air temperature in the open (orange) and experienced air temperature (light blue - either in the open or in the shade or in between, depending on the simulated behaviour of the parrot), with dashed horizontal lines indicating $38{ }^{\circ} \mathrm{C}$ (resting core body temperature) and $45^{\circ} \mathrm{C}$ (near lethal body temperature), and vertical blue lines indicating rainfall $(\mathrm{mm}) ; \mathrm{b}$ ) daily maximum percent dehydration; c) daily cumulative dehydration, with rainfall events $>1 \mathrm{~mm}$ permitting complete rehydration on a given day. (PDF 294 kb)

Additional file 11: Figure S6. Calculations of night parrot environmental conditions and thermal, hydric and energetic state in 2015 at the study site as per Fig. 5, but assuming access to burrows $10 \mathrm{~cm}$ below shaded ground: a) hourly soil surface temperature (red), $4 \mathrm{~cm}$ air temperature in the open (orange) and experienced air temperature (light blue - either in the open or in the shade or in between, depending on the simulated behaviour of the parrot), with dashed horizontal lines indicating $38^{\circ} \mathrm{C}$ (resting core body temperature) and $45^{\circ} \mathrm{C}$ (near lethal body temperature), and vertical blue lines indicating rainfall $(\mathrm{mm})$; b) hourly parrot core temperature (bright red), skin temperature (dark red) and outer feather temperature (orange); c) hourly discretionary energy (assimilated energy minus maintenance costs) when feeding at maximal simulated intake on seed (red), succulents with $25 \%$ water (orange) and succulents with 55\% water (blue); d) hourly evaporative water loss rate; e) daily percentage body mass of water lost (i.e. negative values represent discretionary water); f) daily cumulative dehydration, with rainfall events $>1 \mathrm{~mm}$ permitting complete rehydration on a given day. (PDF $253 \mathrm{~kb}$ )

Additional file 12: Figure S7. The frequency daily or cumulative dehydration of night parrots was predicted to exceed $11 \%$ or $22 \%$ over the summers $1996 / 7$ to $2014 / 15$ at the site under historical and projected (2070 ACCESS 1.3) climate, as per Fig. 6, but assuming access to retreats $10 \mathrm{~cm}$ below shaded ground. (PDF $78 \mathrm{~kb}$ )

\section{Acknowledgements}

MK thanks Katie Date and Monique Winterhoff from Museum Victoria and Devi Stuart-Fox from The University of Melbourne for assistance with measurement of the museum specimens. SM thanks Rachel Murphy for her assistance in the field, and also acknowledges the support of Catherine Bozanich (Fortescue Metals Group) and Bush Heritage Australia. MK and WP acknowledge Natalie Briscoe and Paul Mathewson for their contributions to the model development and testing. All authors acknowledge the contribution that John Young made by his initial discovery of night parrots in western Queensland. We also thank Joseph Forshaw for his insights into night parrot burrowing.

Funding

Funding for field work was provided by Fortescue Metals Group Limited under an agreement between them and the Australian Government 
associated with Environment Protection and Biodiversity Conservation Act (1999) approval EPBC No 2010/5696, condition 10. SM works under contract to Fortescue to develop and implement the required research investment, as outlined in the condition. The modelling work was supported by the National Environmental Research Program's Threatened Species Recovery Hub, under funding from the Australian Government.

\section{Availability of data and materials}

All data generated or analysed during this study are included in this published article [and its additional files].

\section{Authors' contributions}

MK, SM and WP designed the study, SM collected the field data, MK collected the museum data, MK and WP developed the models, MK ran the simulations and analysed the data, MK, SM and WP wrote the manuscript. All authors read and approved the final manuscript.

\section{Authors' information}

MK has had a long-term interest in arid zone biota and has spent the last 12 years developing a system to apply biophysical models in the Australian context. WP was a founder of the field of biophysical ecology and was the original and current co-developer of the models used in this project. SM is a field ecologist with a fascination for the night parrot since childhood and was contracted to undertake the first scientific research project on the species between 2014 and 2016

\section{Competing interests}

The MRK and SAM declare that they have no competing interests. WPP is co-founder of Niche Mapper, LLC.

\section{Consent for publication}

Not applicable.

\section{Ethics approval}

The field research in this project was done under scientific research permits WISP14627114/WITK14627214, and Animal Ethics Committee permit SA 2015/09/521.

\section{Author details}

${ }^{1}$ School of BioSciences, The University of Melbourne, Parkville, VIC 3010, Australia. ${ }^{2}$ Department of Zoology, The University of Wisconsin, Madison 53706, USA. ${ }^{3}$ Research Institute for the Environment and Livelihoods, Charles Darwin University, Casuarina, NT 0800, Australia. ${ }^{4}$ Bush Heritage Australia, Level 1, 395 Collins St, Melbourne, VIC 3000, Australia.

\section{Received: 9 September 2016 Accepted: 28 November 2016}

\section{Published online: 12 December 2016}

\section{References}

1. Ruhl J. Climate change and the endangered species Act: building bridges to the no-analog future. Boston Univ Law Rev. 2008;88(1):07-18.

2. Hoegh-Guldberg O, Huges L, McIntyre S, Lindenmayer DB, Parmesan C, Possingham HP, Thomas CD. Assisted colonization and rapid climate change. Science. 2008;321:345-6.

3. Cooke SJ, Sack L, Franklin CE, Farrell AP, Beardall J, Wikelski M, Chown SL: What is conservation physiology? Perspectives on an increasingly integrated and essential science. Conserv Physiol 2013;1(1):1-23.

4. Walsberg GE. Small mammals in Hot deserts: some generalizations revisited. Bioscience. 2000:50(2):109-20.

5. McKechnie AE, Wolf BO. Climate change increases the likelihood of catastrophic avian mortality events during extreme heat waves. Biol Lett. 2010;6(2):253-6.

6. Suppiah R, Hennessy KJ, Whetton PH, Mclnnes K, Macadam I, Bathols J, Ricketts J, Page CM. Australian climate change projections derived from simulations performed for the IPCC 4th assessment report. Aust Meteorol Mag. 2007:56(3):131-52.

7. Reside A, VanDerWal J, Phillips B, Shoo L, Rosauer D, Anderson B, Welbergen J, Moritz C, Ferrier S, Harwood T, et al. Climate change refugia for terrestrial biodiversity: defining areas that promote species persistence and ecosystem resilience in the face of global climate change. In. Gold Coast: National Climate Change Adaptation Research Facility; 2013.

8. McKechnie AE, Hockey PAR, Wolf BO: Feeling the heat: Aust landbirds and clim chang. Emu 2012, 112(2):i-vii.
9. Gates DM. Biophysical ecology. New York: Springer Verlag; 1980

10. Porter WP, Gates DM. Thermodynamic equilibria of animals with environment. Ecol Monogr. 1969;39(3):227-44.

11. Porter WP, Budaraju S, Stewart WE, Ramankutty N. Calculating climate effects on birds and mammals: impacts on biodiversity, conservation, population parameters, and global community structure. Am Zool. 2000;40(4):597-630.

12. Kearney MR, Porter WP. NicheMapR - an R package for biophysical modelling: the microclimate model. Ecography. 2016.

13. Jones DA, Wang W, Fawcett R. High-quality spatial climate data-sets for Australia. Aust Meteorol Oceanogr J. 2009;58:233-48.

14. McVicar TR, Van Niel TG, Li LT, Roderick ML, Rayner DP, Ricciardulli L, Donohue RJ. Wind speed climatology and trends for Australia, 1975-2006: capturing the stilling phenomenon and comparison with near-surface reanalysis output. Geophys Res Lett. 2008;35(20):L20403.

15. Collar NJ. Psittacidae (parrots). In: del Hoyo J, Elliott A, Sargatal J, editors. Handbook of the birds of the world, Sandgrouse to cuckoos, vol. 4. Barcelona: Lynx Edicions; 1997.

16. Andrews FW. Notes on the night parrot. Trans Proc R Soc S Aust. 1883;6:29-30.

17. Cleland JB. The history of ornithology in south Australia. Emu. 1936;36:197-221.

18. Menkhorst P, Ryan E: CH. McLennan ('mallee Bird') and his aboriginal informant jowley: the source of early records of the night parrot pezoporus occidentalis in Victoria? Mem Mus Victoria. 2015;73:107-15.

19. Wilson $\mathrm{H}$. Notes on the night parrot, with references to recent occurrences. Emu. 1937;37:79-87.

20. McGilp JN. Geopsittacus occidentalis, night-parrot. S Aust Ornithol. 1931;11:68-70.

21. Murphy S. Night parrot (pezoporus occidentalis) research plan. In. Yungaburra, QLD and Perth: Map IT and Fortescue Metals Group; 2014.

22. Murie J. On the nocturnal ground-parrakeet (geopsittacus occidentalis, Gould). Proc Zool Soc London. 1868;1868:158-65.

23. McFarland D. The biology of the ground parrot, pezoporus wallicus, in Queensland. I. Microhabitat use, activity cycle and diet. Wildl Res. 1991;18(2):169-84

24. McNab A, Sanders MG, 4/5/6. Consumption of exotic grass seeds (Poaceae: Cynodon dactylon) by the eastern ground parrot (pezoporous wallicus). Queensland Nat. 2014;52:82-4.

25. Boles $\mathrm{W}$, Longmore $\mathrm{N}$, Thompson $\mathrm{M}$. A recent specimen of the night parrot geopsittacus occidentalis. Emu. 1994:94(1):37-40.

26. Ellis R. Bush safari. Adelaide: Rigby Publishers; 1982

27. Australia's bioregions (IBRA) [https://www.environment.gov.au/land/nrs/ science/ibra]. Accessed 1 Dec 2016.

28. Gueymard C. SMARTs, a simple model of the atmospheric radiative transfer of sunshine: algorithms and performance assessment. In. Cocoa: Florida Solar Energy Center; 1995.

29. R Development Core Team. R: A language and environment for statistical computing. Vienna: R Foundation for Statistical Computing; 2012. URL http://www.R-project.org/. ISBN 3-900051-07-0.

30. Porter WP, Munger JC, Stewart WE, Budaraju S, Jaeger J. Endotherm energetics: from a scalable individual-based model to ecological applications. Aust J Zool. 1994;42:125-62.

31. Porter WP, Vakharia NP, Klousie WD, Duffy D. Po'ouli landscape bioinformatics models predict energetics, behavior, diets and distribution on Maui. Integr Comp Biol. 2006:46:1143-58.

32. Briscoe NJ, Kearney MR, Taylor CA, Wintle BA. Unpacking the mechanisms captured by a correlative species distribution model to improve predictions of climate refugia. Glob Chang Biol. 2016;22(7):2425-39.

33. Leeton PRJ, Christidis L, Westerman M, Boles WE. Molecular phylogenetic affinities of the night parrot (geopsittacus occidentalis) and the ground parrot (pezoporus wallicus). Auk. 1994;111(4):833-43.

34. Cade TJ, John A, Dybas Jr. Water economy of the budgerygah. Auk. 1962;79(3):345-64.

35. Greenwald L, Stone WB, Cade TJ. Physiological adjustments of the budgerygah (Melopsittacus undulatus) to dehydrating conditions. Comp Biochem Physiol. 1967;22(1):91-100.

36. Weathers WW, Schoenbaechler DC. Regulation of body temperature in the budgerygah. Melopsittacus undulatus Aust J Zool. 1976;24(1):39-47.

37. Prinzinger R, Preßmar A, Schleucher E. Body temperature in birds. Comp Biochem Physiol A Physiol. 1991:99(4):499-506.

38. Schmidt-Nielsen K, Hainsworth FR, Murrish DE. Counter-current heat exchange in the respiratory passages: effect on water and heat balance. Respir Physiol. 1970;9(2):263-76.

39. Chato JC. In: Chao BT, editor. Advanced heat transfer. Urbana: U of III. Press; 1969. p. 395-412. Heat transfer in bioengineering. In. 
40. McKechnie AE, Wolf BO. The allometry of avian basal metabolic rate: good predictions need good data. Physiol Biochem zool: Ecol Evol Approaches. 2004;77(3):502-21.

41. Hoffman TCM, Walsberg GE, DeNardo DF. Cloacal evaporation: an important and previously undescribed mechanism for avian thermoregulation. J Exp Biol. 2007;210(5):741-9.

42. Hainsworth FR. Animal physiology. Reading: Addison-Wesley Publishing Company; 1981.

43. Lindstrom A, Kvist A. Maximum energy intake rate is proportional to basal metabolic rate in passerine birds. Proc R Soc Lond Ser B Biol Sci. 1995; 261(1362):337-43.

44. Waterhouse CE, Hutcheson LM, Booker KM. Food consumption and palatability studies in budgerigars. J Small Anim Pract. 1961;2(1-4):175-84.

45. Kearney MR, Shamakhy A, Tingley R, Karoly DJ, Hoffmann AA, Briggs PR, Porter WP. Microclimate modelling at macro scales: a test of a general microclimate model integrated with gridded continental-scale soil and weather data. Methods Ecol Evol. 2014;5:273-86.

46. Watterson IG, Hirst AC, Rotstayn LD. A skill score based evalutation of simulated Australian climate. Aust Meteorol Oceanogr J. 2013;63:181-90.

47. Ashcroft MB, Gollan JR. Fine-resolution ( $25 \mathrm{~m}$ ) topoclimatic grids of nearsurface $(5 \mathrm{~cm})$ extreme temperatures and humidities across various habitats in a large $(200 \times 300 \mathrm{~km})$ and diverse region. Int J Climatol. 2012;32(14):2134-48.

48. Kearney M, Porter WP. Mechanistic niche modelling: combining physiological and spatial data to predict species' ranges. Ecol Lett. 2009;12:334-50

49. Kearney MR, Simpson SJ, Raubenheimer D, Kooijman SALM. Balancing heat, water and nutrients under environmental change: a thermodynamic niche framework. Funct Ecol. 2013:27(4):950-66.

50. Mitchell N, Hipsey MR, Arnall S, McGrath G, Bin Tareque H, Kuchling G, Vogwill R, Sivapalan M, Porter WP, Kearney MR. Linking eco-energetics and eco-hydrology to select sites for the assisted colonisation of Australia's rarest reptile. Biology. 2013;2(1):1-25.

51. Burton S, Perrin MR, Downs CT. Thermal biology of African lovebirds and Australian grass parakeets. J Therm Biol. 2008;33(6):355-62.

52. Angilletta MJ, Cooper BS, Schuler M, Boyles JG: The evolution of therma physiology in endotherms. Frontiers in Bioscience 2009, in press.

53. Maclean GL: Ecophysiology of Desert Birds. Berlin: Springer-Verlag

54. Schmid WD. Temperature gradients in the nasal passage of some small mammals. Comp Biochem Physiol A Physiol. 1976:54(3):305-8.

55. Humphries MM, Careau V. Heat for nothing or activity for free? evidence and implications of activity-thermoregulatory heat substitution. Integr Comp Biol. 2011;51(3):419-31.

56. Sunday JM, Bates AE, Kearney MR, Colwell RK, Dulvy NK, Longino JT, Huey RB. Thermal-safety margins and the necessity of thermoregulatory behavior across latitude and elevation. Proc Natl Acad Sci. 2014;11(15):5610-5.

57. Schodde R, Mason IJ. Nocturnal birds of Australia. Melbourne: Lansdowne; 1980.

58. Forshaw JM, Cooper WT. Australian parrots, second edition edn. Lansdowne: Melbourne; 1981.

59. Kearney MR, Wintle BA, Porter WP. Correlative and mechanistic models of species distribution provide congruent forecasts under climate change. Conserv Lett. 2010;3(3):203-13.

60. Sotherland PR, Rahn H. On the composition of bird eggs. Condor. 1987;89(1):48-65.

61. Teixeira CMGL, Sousa T, Marques GM, Domingos T, Kooijman SALM. A new perspective on the growth pattern of the wandering albatross (Diomedea exulans) through DEB theory. J Sea Res. 2014;94:117-27.

\section{Submit your next manuscript to BioMed Central and we will help you at every step:}

- We accept pre-submission inquiries

- Our selector tool helps you to find the most relevant journal

- We provide round the clock customer support

- Convenient online submission

- Thorough peer review

- Inclusion in PubMed and all major indexing services

- Maximum visibility for your research

Submit your manuscript at www.biomedcentral.com/submit
() Biomed Central 